\title{
THE AMERICAN CONSERVATIVE RESPONSE
}

The Commune marked a decisive moment in America's historical and political consciousness and in her image of her own revolutionary tradition. The impact of the Commune is best appreciated when the response it evoked is placed in the context of America's reaction to France's revolutionary efforts from the summer of 1789 to the spring of $1968 .{ }^{1}$ In these two centuries the prevailing attitude in the United States shifted steadily from an openness toward the necessity of revolutions to a position of fear and dread of this historical action. Americans at all times used the French experience as a mirror to examine their own conflicts and contradictions, their greatest expectations, their gravest anxieties, their receptivity to innovation, and their hostility to change. Each crisis in France polarized opinion in the United States and on some occasions such as the Commune the resulting tensions concretely influenced the course of the nation's history.

During France's Great Revolution a pattern of American response was established that essentially served during each crisis. At first a welcoming of France's efforts to exchange republican institutions for a monarchical and hierarchical society elicited praise and encouragement. When the revolution entered its times of troubles opinion divided and became uncomfortable at the prospect of revolutionary dictatorship and violence. The intensity of the struggle between revolutionists and counter revolutionaries brought in America confusion, ambivalence, loss of enthusiasm and a mounting preference for the preservation of

1 The only effort to survey America's response to France's revolutions is that of Eugene N. Curtis, "American Opinion of the French Nineteenth-Century Revolutions", in: The American Historical Review, XXIX (1924), pp. 249-270. The standard account of America's reaction to the French Revolution of 1789 is Charles Hazen, Contemporary American Opinion of the French Revolution, Baltimore 1897. The best account of American reaction to 1848 is that of Merle Curti, "The Impact of the Revolutions of 1848 on American Thought", in: Proceedings of the American Philosophical Society, XCIII (Philadelphia 1949), pp. 209-215. 
property and order. During each of France's subsequent revolutions those critical of her revolutionary experiments mobilized widening support and succeeded in turning this reaction against their real opponents those persons and groups in America who threatened their own hegemony and power. By the time of the Commune, the reinforced pattern of reaction to France's revolutions enabled the established forces in American society to focus the fears aroused by the Commune against all proposals for reform or radical change in America. After the Commune the antirevolutionary defenses developed during its brief history functioned as a reflex action automatically converting every French and European revolutionary gesture into a direct challenge to the American achievement.

The American reaction to and interpretation of the Commune occurred at the period in American history of maximum violence of every sort. Nearly every form of violence, political, criminal, vigilante, racial, urban, freelance combined to make the post-civil war the most violent era in the history of this nation. ${ }^{1}$ This violence, subscribed to and feared, ruled the collective psychology of American society during these decades. The response to the Commune was the reaction of a society fearing its own violence and facing in its future the realization of its own most dreaded apprehensions in labor and racial strife. Official and public reaction to the Commune was dominated by the need of those most intimately experiencing the violence of their own society to find in the Commune the rationale to support official acts of pre-emptive violence accepted as the violence needed to end all violence.

Violence was something American observers understood with the exceptional perception that comes from constant experience. Even before the Commune was established, Elihu Benjamin Washburne (1816-1887), Envoy Extraordinary and Minister Plenipotentiary to the Versailles government, warned Washington on March 17, 1871, that, although he expected the new Republic to survive, the activity of the National Guard on Montmartre was disconcerting and "it must be confessed that the condition of the lower and working classes of Paris is alarming". ${ }^{2}$ For a brief time Washburne hoped that men of order,

1 Sheldon G. Levy, "A 150-Year Study of Political Violence in the United States", in: Hugh Davis Graham and Ted Robert Guss, Violence in America: Historical and Comparative Perspectives, New York 1969, p. 89, and see also Richard Maxwell Brown, "Historical Patterns of Violence in America", ibid., pp. 45-84.

245 th Congress 2 nd Session. Senate Executive Document No. 24. Vol. I. FrancoGerman War and Insurrection of the Commune. Correspondence of $\mathrm{E}$. $\mathrm{B}$. Washburne, Envoy Extraordinary and Minister Plenipotentiary of the United States to France, Washington 1878, p. 157. 
property, and character would prevail, but by March 23, he reported that France was undergoing a "new reign of terror", and Paris in a situation "without parallel in history"." Two days later Washburne informed his government that in Paris "anarchy, assassination, and massacre hold high carnival". ${ }^{2}$ He subsequently assured Washington that the election for the municipal council "was a perfect farce". For Washburne the Commune could only be appreciated as an act of madness and macabre folly unrelated to the political and historical reality of French society; an action to be perceived as fundamentally antihistorical, as antihuman as the actors in the drama of madmen. When the Commune failed, Washburne summarized the official and conventional American judgment on the Paris revolt. The Commune was to be viewed as the example of an insurrection "such as has never been known in the annals of civilization", 3 to be appreciated as an exclusive affair of "murder, assassination, pillage, robbery, blasphemy". The emphasis on the pathology and criminality of the Commune was necessary in order to deny historical authenticity to a revolt bearing the social significance of the Commune.

Washburne's reaction to the Commune was largely shared by his countrymen. ${ }^{4}$ Considerable sympathy, however, had existed in America for France during the Prussian invasion, and funds were collected throughout the country to aid French citizens in distress. This sympathy now dried up to be replaced by repugnance, distaste, dread. Yet there was some limited understanding of the social problems that faced the new republic, but it was precisely the Commune's particular answers to these difficulties that evoked the greatest outrage in America. As early as March 23, Edwin Godkin's (1831-1902) important weekly magazine The Nation characterized the news from France as that of "The 'Red' Rising in Paris". ${ }^{5}$ The Nation admitted that the proletarian population of Paris chronically experienced great trauma in making the transition from the conditions of prudence, religion, illiteracy of the countryside to life in the capital city. These problems of adjustment were, the

1 Ibid., 164.

2 Ibid., 168.

s Ibid., 209.

4 The most valuable discussion of the Commune and the American press is that of Samuel Bernstein, "The American Press Views the Commune", in: Samuel Bernstein, Essays in Political and Intellectual History, New York 1955, pp. 169-183. See also Samuel Bernstein, The First International in America, New York 1965, and the earlier contributions by A. Landy listed in J. Rougerie and G. Haupt, "Bibliographie de la Commune de 1871", in: Le Mouvement Social, No 38 (1962), p. 75.

5 "The 'Red' Rising in Paris", in: The Nation, March 23, 1871, p. 193. 
Nation argued, only made the more dangerous by the presence in Paris of those who advocated social experimentation, and who exploited the confused and miserable working class by holding before them the illusory promise of a transformation in the social order.

As the events of the Commune unfolded, it became increasingly important for the Nation to remind its readers that the Commune illustrated the universal threat of labor to property and order. The Commune had proved, the Nation warned on May 18, what "veritable workingmen" can do even when considered "Iunatics and loafers". ${ }^{1}$ The Nation considered especially harmful the inspiring legend that would grow after the Commune was crushed by "reaction"; this myth could only serve, the Nation reasoned, to further extend class divisions and embolden the false cause of labor. The danger represented by labor's misreading of the Commune was, however, regarded by the Nation as less disturbing than that given by intellectuals and humanitarians in America and England who provided a sympathetic audience to the "new doctrine that society, as at present constituted is a hideous contrivance for the oppression of the poor..."2 Godkin's magazine regarded it as obvious that any sustained disadvantages experienced by workingmen was due to their "want of thrift, foresight, self-restraint, and mutual confidence". ${ }^{3}$ While true confidence between labor and capital, the Nation concluded, would come through the initiative of Capital acting in its own enlightened self-interest and supported by Christian morality.

While the Nation was somewhat distinguished by its view that real social questions were central to the action of the Commune much of the daily press in America regarded the Commune only as a horror story. The Chicago Tribune, which indentified itself as "The Great Radical Republican Newspaper of the West", had shown genuine care for France during the Prussian war, a feeling encouraged by Illinois farmers of French descent. The Tribune, however, quickly adopted a tone of hysteria in treating the news of the Commune. Significantly, the actions of the Communards were described as worse than that of the American Comanche Indians. In a period when the American Indian was being finally confined, defeated, and decimated by the concluding series of Indian wars the vulgar rationale that "the only good Indian is a dead one", was easily translated into the premise that the only good Communist is a dead one. In the first week of the Commune the Tribune eagerly advised Versailles to find someone who

1 "The Commune and the Labor Question", in : The Nation, May 18, 1871, p. 334.

2 "Communist Morality", in: The Nation, June 15, 1871, p. 413.

3 "The Future of Capital", in: The Nation, June 22, 1871, p. 429. 
would "mow down the mob without compunction of hesitation, as General Cavaignac mowed them down in 1848". ${ }^{1}$ The critical demand here was that those who would do the killing of the Communards act "without compunction", put on the necessary protective protection so that their consciences could not be pricked by scruples before the deed or feel any subsequent guilt; the psychological shielding necessary for continued counter violence against all dissent.

The Chicago Tribune did not give to the Commune the steady and full attention that the New York Herald paid to the insurrection. The Herald, in keeping with its reputation for covering events in Europe, through extensive daily news stories and editorials interpreted the Commune with the assistance of every American stereotype concerning France. The Herald early in March faithfully reported an interview with Victor Hugo on the eve of the Commune in which the poet assured America that France's new republic represented the desire of all France except her aristocrats and bad citizens. ${ }^{2}$ For the Herald this optimism and confidence underscored the deviant place of Paris in France's life and history. Paris, the city of mobs and madmen, could be expected to recreate the Reign of Terror. When these fears seemed to be confirmed, the Herald urged Versailles to destroy the city and its inhabitants in order to save true France. "Let it [Versailles]", the Herald editorialized, "make Paris a heap of ruins if necessary, let its streets be made to run rivers of blood, let all within it perish, but let the government maintain its authority and demonstrate its power. Let it crush completely every sign of opposition, no matter what the cost and teach a lesson that Paris and all France will remember and profit for centuries to come."3 France was expected by this violence against her own citizens to expiate for her sin of periodically shocking other nations by her revolutionary history. When rumors were circulated that Paris and the Communard might be induced to surrender the Herald in desperation warned: "No peace can be obtained except by annihilating them, and, though the streets of Paris may be made to run with blood, let there be no concession [...] until the possibility of a recurrence of late events is forever rendered impossible."4 The demand that Parisians "drink their own blood" revealed more about American society than it did the French experience. A measured response to

1 "The Massacre in Paris", in: The Chicago Tribune, March 22, 1871.

2 "Victor Hugo", in: The New York Herald, March 24, 1871.

3 "Progress of the War - Against the Paris Commune", in: The New York Heraid, April 21, 1871.

4 "The War Against the Commune - Progress of the Siege", in: The New York Herald, May 17, 1871. 
dissent became in America less and less likely as the nation succombed to a violent psychological reaction to every challenge to the existing order.

The actual violence in Paris was not solely responsible, however, for releasing the ungarded anxiety in America. The social program represented by the Communards provoked in America an unlimited will to violence in the defense of conventional beliefs. After the fall of the Commune, the Herald eager to find reasons for confidence in the future of the French Republic now admitted that in truth the Communards had been less radical than the participants in the June days of 1848. The defeated Communards were now complimented for having supported the idea of local autonomy against the centralized state. "Even the Commune", the Herald declared, "seemed to have eschewed the theories of the socialists of 1848 [...] the Paris leaders contended for sound republican principles that of locale self-government. There was no socialism in that." 1 The only intolerable action was the advocacy of socialism. When depicted as a social revolution the Commune functioned in America to further reduce inhibitions against violence directed at those expressing minority and unpopular social expectations. The violence of the 1870's and during the labor strikes of 1877 would illustrate the consequences for a society that willed to be free of inhibiting mechanisms against official violence.

In the United States the events of the Commune were fed into a kind of simulator created by the press and public discussion that permitted important groups in America to experimentally choose the options they would employ if a similar crisis occurred in their country. With the help of this instrument they concluded their own simulated revolution by adapting and refining a commitment to repression. Yet there had been one effort in the reconstruction period following the Civil War to build new flexibility and opportunity into the institutional structure of American society. This attempt was particularly striking in the steps taken to widen the protection of the citizen versus the power of the State by adding important amendments to the Constitution. Significantly this major effort would also be subject to the impact of the Commune and the fears it unleashed in American society.

The Fourteenth Amendment ratified by the States in 1868 was designed to protect the civil rights of the emancipated slaves and to reconfirm and strengthen these rights for all citizens. The most important provision of the Amendment was the protection provided in Section 1: "No State shall make or enforce any law which shall abridge

1 "France and the Movements in Europe - Thiers Can Make Himself the First Man of the Times", in: The New York Herald, June 10, 1871. 
the privileges or immunities of citizens of the United States, nor shall any State deprive any person of life, liberty or property, without due process of law..." The due process clause designed to ensure the rights of Afro-Americans and all citizens was, however, through an unexpected strategy soon used by business corporations to challenge the right to regulate them in the public interest. The success of the business community virtually built into the Constitution the doctrine of laissez faire and insured for corporate interests the powerful resources of the Federal government in their struggles with labor.

The Supreme Court in the famous Slaughter House Cases (1873) reaffirmed that the Fourteenth Amendment was restricted to the protection of the civil rights of persons, and in so doing upheld the regulatory power of the States over those doing business within their jurisdictions. But Justice Stephen J. Field (1816-99), an Associate Justice of the Court (1863-97), entered an important dissent to the majority decision in the Slaughter House Cases. ${ }^{1}$ This dissent occurred at a time when his philosophy of law was shifting from that of a liberal judge to that of a philosophy in favor of restricting the power of the courts, and to a position actively hostile to social legislation, that challenged in his view the rights of property which he argued were to be equally protected by the due process of the Fourteenth Amendment. ${ }^{2}$ Justice Field in 1876 dissented in the case of Munn v. Illinois, and at this time gave his precedent making opinion that: "The same liberal construction which is required for the protection of life and liberty, in all particulars in which life and liberty are of any value should be applied to the protection of private property."3

Within a few years the interpretation of Justice Field prevailed and corporations were granted the protection given to persons by the Fourteenth Amendment. This made it difficult for the States to regulate questionable business practices and equally difficult for labor to contend against the power of the corporations. Justice Field's influential defense of the Lockean philosophy of possessive individualism had a major impact on the development of American society. His personal history takes on, therefore, an importance that would not normally be appropriate for a jurist of conventional talents. Carl B. Swisher, the biographer of Justice Field, has argued that it was Field's terror at the "menace of communism" which induced him to establish every barrier

1 For the Slaughter House Cases see Charles Fairman, American Constitutional Decisions, New York 1950, pp. 306-324. Field's dissent is given on pp. 319-321.

"Howard Jay Graham, "Justice Field and the Fourteenth Amendment", in: Howard Jay Graham, Everyman's Constitution, Madison 1969, p. 115.

3 Munn V. Illinois, 94, United States Supreme Court, 113 (1877). For Justice Field's dissent p. 142. 
to protect property because of his fear that, "if in one instance the masses were given the power of interference with the property of wealthy individuals and great corporations, there was no possibility of knowing where the interference might stop."' Howard Jay Graham, the profound scholar of the Fourteenth Amendment, has in addition established that it was the events of the Commune that concretized Field's fears and reinforced all his anxieties concerning the direction of a democratic society. Graham proposes that "The evidence is clearly such to mark the Paris Commune as an important pivot in American Constitutional history, a chronological and doctrinal key both to Justice Field's career and to the historical evolution of the Fourteenth Amendment."2 The shock of the Commune when filtered through the press and magazines such as the Nation led Field to associate sectional strife, and labor unrest in America with the events in Paris. Identifying the violence in America, and in particular violence in the Amador mine fields of California, with the violence in Paris, Field was determined as a Justice of the Supreme Court to do all he could to prevent the reoccurrence in America of the French crisis. His success in interpreting the Constitution in favor of property and business prevailed until the Roosevelt years. No other development in American history is so closely related to the history of France. Howard Jay Graham concludes that through the formal opinions of Justice Field on the Supreme Court the Commune has a unique place in American history:

"By conditioning a state of mind which stigmatized as 'Communist' the efforts of agrarian and labor groups to control the abuses of unregulated and publicly subsidized business, the Paris Commune tragically confused American social thinking, came close to subverting the basic trends of democracy and set in motion the forces which caused constitutional theory to run counter to social needs. [...] in the light of the breach between theory and practice it is not too much to say that the Paris Commune helped lay the foundations for a constitutional crisis which took generations to mature and which ended only recently in repudiation of the Fieldian viewpoints." 3

The Commune was a turning point in the history of America's selfimage, constitutional practice, attitudes towards social reform, openness and hostility to the historical experiments of other evolving

1 Carl B. Swisher, Stephen J. Field, Craftsman of the Law, Washington, D.C., 1930, p. 429.

2 Graham, op. cit., p. 117.

3 Ibid., 149-150. 
societies. The response to the Commune was not, however, a moment of discontinuity in the traditions of American society, but was a decisive time in the cumulative effort of this nation to cast off the more disturbing implications of its own revolutionary origins. The Commune was a critical stage in the development of the counter-revolutionary direction begun as early as 1793, strengthened in 1830 , reinforced in 1848 , and hardened in 1871.

In the years following the Commune prevailing opinion in America reverted again and again to the fears articulated during the Commune concerning socialism, anarchy, order. These anxieties governed American reaction to the Russian Revolution of 1917, the Spanish civil war of 1936, the revolutions in Asia and the Third World, the events in France of May-June 1968..$^{1}$ Minority opinion did attempt from time to time to win some toleration of social change and to support the historical privilege of societies to shape their own destinies. In the main, however, the fear burnt into the collective psychology of America during the Commune supplied the paradigm to guide her response to Europe's revolutions. Initially, as in the eighteenth century and first decades of the nineteenth century, the revolutionary destruction of an ancien regime was granted some approval, but as soon as continuing conflict and the attempt at social reconstruction became visible American's hastened to express their fear and censure. In all cases this resentment was equally directed at domestic dissenters as well as foreign innovators. The Saturday Evening Post, a weekly enjoying a circulation of two million at the time of the Russian Revolution, unhesitatingly assured its readers in its editorians and fiction that revolution meant pillage, anarchy, the old French errors of Robespierre and the Terror. Without reservation the defense of capital was accepted as the only issue. An editorial in the Post of 1919 confidently asserted the magazine's trust that the "silent majority" of American farmers, workers, teachers, children and housewives were in agreement that capitalism is "the best way". ${ }^{2}$ The Post was certain that this majority would support the use of force to crush "harshly" any comparable challenge to the American way. America had begun as a society in revolt seeking the "decent opinion of mankind", but by the twentieth century revolutions were

1 For American response to the Russian Revolution see Phillip Sheldon Foner, The Bolshevik Revolution, its impact on American Radicals, Liberals, and Labor, New York 1967, and Christopher Lasch, The American Liberals and the Russian Revolution, New York 1962; and for the Spanish Civil War, Alan Guttman, Wound in the Heart: America and the Spanish Civil War, New York 1962.

2 "Both End and the Middle", in: The Saturday Evening Post, November 1, 1919. 
denied by a majority of American citizens any claim to respect or encouragement. They were instead regarded as evoking the obscene disapproval of good men, the disdain of men of average sensibilities living in a post-revolutionary nation.

By 1968 France was to many Americans an interesting case history of a society in trouble, but her example was, for a nation having a population and resources four times that of France, felt to be a less intimate threat to American institutions and values. The very international character of this rebellion of youth reassured Americans that the basis of their own society was solid enough to withstand attacks from this vocale minority segment of society. The assault by critical youth, though irritating and provoking outrage, was less alarming than the revolutions of the nineteenth and twentieth centuries that had posed the possibility that the labor and urban populations might be set in motion.

Yet when the students at Columbia University in New York City occupied the buildings on their campus in April 1968 they joyfully regarded this action as an historical link with the Paris Commune. Mark Rudd, the most famous of the student leaders in interpreting their goals, declared: "Historically the Paris Commune of 1871 has long been a symbol of revolutionary will, dedication and struggle. If just for the identification with the Paris Commune and the international socialist revolutionary movement, 'Commune' is a proudname for our liberated buildings." 1 As the Commune approached its hundredth anniversary the memory of this revolution received from American college students enthusiastic gratitude for its historical example. Only the two hundredth anniversary of the Commune will enable historians to judge whether the Commune in 1968 entered the American imagination as a treasured symbol, or whether it will remain what it was for the nineteenth and twentieth centuries: a revolution evoking the least generous responses of American society.

1 Mark Rudd, "Symbols of the Revolution", in: Up Against the Ivy Wall: A History of the Columbia Crises, edited by Jerry L. Avorn and Richard Friedman, New York 1968, p. 294. 